\title{
A BALLAD \\ ABOUT SAINT ANDREW AND THE CANNIBALS, ATTRIBUTED TO SAINT EPHRAIM ${ }^{1}$
}

\author{
Michel VAN EsBroeck, S.J. \\ INSTITUT FÜR SEMITISTIK \\ LUDWIG-MAXIMILIANSUNIVERSITÄT, MÜNCHEN \\ GERMANY
}

[1] The Proceedings of the Symposium Syriacum which took place at Uppsala in 1996 will contain my French translation and Syriac edition of a ballad preserved in the Vatican MS Syr. 117 and four other MSS, including the very corrupt acephalous text in British Library Add. MS 14656. Andrew Palmer has kindly translated the first seventy-six heptasyllabic couplets into English iambic pentameters for this paper.

Upper-case letters in the right margin indicate adjustments made by A. Palmer to the Syriac text presented by the author, as follows: $\mathrm{A}=$ add a word; $\mathrm{E}=$ emend a word; $\mathrm{O}=$ omit a word; words underlined show the influence of Ephraim's diction $(29,31$, 45), or of his "balancing" style (62); passages in italics are clumsy phrases which show an imperfect knowledge of the Syriac language; words between square brackets are added to fill out the English metre and have no authority; no attempt has been made to improve on the doggerel style of the original: Andrew Palmer]

1 The notes of the Special Issue Editor, Dr. Andrew Palmer, appear in square paranthesis. 
TITLE IN MS: Ballad (memrä) chanted (or "spoken") by Mor Afrem about Andrew, the Apostle, when he was sent to the Land of Kalbin ["Land of Dogs"]. E

Called by our Lord, his [twelve] Apostles went to every quarter [of the earth to preach];

And each of his Evangelists received

his portion of the countries [in the world].

To Simon He entrusted [that of] Rome;

to Mark He gave [all] Egypt with its land;

For Thomas He selected India;

and Ephesus He set aside for John.

5 The country of Kalbin He chose to be the field for Andrew's missionary work.

Now God's Apostle knew how [burdensome and] awkward his allotted journey was;

Before [the Lord's] Disciples gathered there, he groaned and then began to weep, [and said:]

"My brothers, [please, I beg you,] don't send me [to preach] among that race of cannibals!

This country which has fallen to my lotno man of justice ever entered there.

10 I'm old [and doddering] and very weak;

I do not even have the strength to walk.

How can I go without an entourage,

with nothing of my own-no horse, no mule; $\mathrm{O}$

With neither gold nor silver [in my purse]?

My brothers, [please,] have pity on my age!

Give me another country to convert!

I'll go there [gladly and evangelise]."

"Oh no, our brother, [no]! Not on your life!"

the other pupils of the Lord replied.

15 'It's none of us that gave to you that place.

You've got it and there's nothing you can do! 
The One who gave to Thomas India, the same gave you the country of Kalbin.

Accept his word and go in peace; then God will bring you quickly to your journey's end.

And when your place of exile gets you down, then God will give you succour, [if you pray]."

He wept; but saw that he could not escape the tidings of his [harsh] apostleship.

20 He wanted to convert the nations, but his place of banishment was bitter news,

Considering old age, so close at hand, attended by enfeeblement [and pain].

He passed the Upper Room without delay; he passed the gateway in the city-wall;

His purpose was to be alone to weep in varied sights of [all] the monuments.

In every place to which he came he knelt [on bended knee] and there began to pray.

25 He saw the structures of Jerusalem with [all] the buildings that surrounded it:

"Be well, O city David built! Adieu!

For who can say if I'll come back to you?"

He prayed with groaning to the Lord, and [He,] the Lord, performed the thing that he desired;

And what ensued was such a miracle as never has been heard of [anywhere]:

Our Lord came down, as He came down [before] and levelled out a path [for us] on earth.

30 His guise was that of one whom commerce drives abroad [on distant journeys far from home].

He painted semblances of angels there and made them seem like [ordinary] men.

He carved and from combustion brought up beasts and tethered them beside the 
[On these] He placed the semblances of loads, as if $\mathrm{He}$ were a trading man [indeed]. All these were meant to lift depression from [his] Pupil by a stimulating sight.

35 The Blessèd Man looked up and saw, at rest, a caravan of [animals and] men.

Without delay he hurried up to see what kind of [trading] people they might be.

He looked and saw that they were nothing like the native people of Jerusalem.

[Rather,] to judge by their appearance, they were born among the Egyptians [by the Nile].

Approaching them without delay, he asked, "[Good] men! From whence are you?

And who is he,

40 This great, [majestic] man who [goes] with you?

Reveal [your secrets]! Tell me [everything]!"

They answered, "We are merchants and we go [with cargo] to the Country of Kalbin.

Each year we cross the borders of [that land], the Country of Kalbin, [to sell our wares]."

The Blessèd Man, delighted, heard [their words] and thanked [his] God and offered praises up.

He urged the young men further, "I would like to see the man who leads you[r caravan]."

The Skyborn Ones Who Never Go To Sleep brought [Andrew] to their Lord and stood him there.

So handsome and so fine is his attire; so noble and so splendid is his rank.

Magnificent the tent put up for Him; yet in appearance He's a Son of Earth.

Our Lord called his Disciple, stretching out his hand and giving it to him, the way He stretched his hand out [once] among the waves, and put it into Simon Peter's own, 
50 And welcomed him with, "Peace be with you, so elderly and humble and forlorn! [friend,]

Reveal to me from where you come and [please] explain to me what brings you to this place!" The Apostle spoke to our Redeemer, "[Sir,] your servant is a poor [and agèd] man.

But I desire to journey to that land to which [with all this merchandise] you go." Our Saviour did not ask him to explain the reason why he wished to travel there.

55 Instead, He gave him comfort and made all his [further] questions seem superfluous By saying, "I'm so glad that you have come, because I see your [venerable] age. Will you become our chief, instead of me, the good adviser of our company? Whenever I would emphasise your rank, you'll eat with me at table very well.

Take for yourself a camp-bed like my own; and I shall find a horse for you to ride,

60 To give your seniority a rest from great exertion and vexatiousness."

At this the old and humble man arose and knelt before the "Man' and worshipped

Him;

that Son of Earth began to bless the Lord, the very One who modelled Adam's frame:

"Because of all your kindnesses to me you'll see, I hope, the kindnesses of God.

I trust in God, moreover, that the way that lies before you will be blessed by Him.

65 But now I must go back inside the walls:

I'll come to you again without delay."

Our Lord said, "Go! May all be well with you!

I've told you my intention perfectly; 
But if you want to journey on with us, come back to us [as] quickly [as you can],

Since we shall make a start without delay, according to the custom that we hold?'

From what He said to his Disciple_- "Come!

Get back to us [as] quickly [as you can]!”-

70 The Apostle learned, [as Jesus taught before,] to sever [earthly] cares of every kind.

Rejoicing, the Disciple joined his friends, [where they were gathered,] in the Upper

Room.

He chuckled and his countenance was glad, suffused [with pleasure], totally consoled:

"I'm leaving now! May all be well with you!

See, brothers! I am headed Gospel-wards,

As He desires. But don't forget me, [friends!]

Remember me in [all] the prayers [you say]!

75 When offering sweet incense up to God, [please don't neglect] a spoonful in my name!

Remember me in praying, as you would a dead man, gone to [see] the Underworld!"

\section{INTRODUCTION}

Comment on couplets 1-13 and 49-50: The Apostles are artificially reduced to four, matching the four regions (West: Peter; South: Mark; East: India; North: Ephesus). Andrew refuses to go to the uncivilised land of Kalbin (the Chalybes). The List of the Apostles and their Fields of Mission is a literary genre, serving as a claim to legitimacy; the presentation in the ballad is highly original by comparison; there is no mention of Constantinople. ${ }^{2}$ There seems to be a concern to highlight the paradox that Andrew, who was the first to be called (Greek: protokletos), was nevertheless second to Simon Peter; Christ stretches out his hand to Andrew as He had

2 Compare M. van Esbroeck, "Neuf listes d'apôtres orientales," Angustinianum 34 (1994): 109-99. 
done to Simon Peter when he began to sink while walking over the water towards his Lord.

Summary of couplets 77-153: The Apostles send Andrew on his way with their blessing, but wonder how he could have changed his mind so quickly. Andrew embarks on a ship and goes to sleep; meanwhile the Lord orders the elements to make a storm. With an allusion to Ephesians 5:14, the Lord wakes Andrew and Andrew commands the waves in the name of Jesus of Nazareth. The sea obeys and Andrew preaches to the stupefied sailors. Couplets 121 and 122, part of his sermon, contain an archaic formulation, reminiscent of Ephraim: "He entered her hearing through the ear and settled in the womb of the one who bore Him; / by his birth He levelled a path [for others?], but $\mathrm{He}$ did not break the maidenhead of the one who bore Him." The captain (Jesus in disguise) blesses Andrew. They arrive in the Land of Kalbin. The captain tells Andrew to come back if any difficulty arises.

Summary of couplets 154-244: Andrew reaches the street of a town and is attacked by a crowd of people barking like dogs. (Kalbin is the Syriac for "dogs.") He runs away and comes to the beach, where he is met by the fragrance of incense and infers that the captain of the ship (which has disappeared) was Christ Himself. He prays and falls asleep. Christ appears to him in a dream and promises his help. Andrew wakes and returns to the town. With the sign of the Cross he causes the hands, the feet and the tongues of the people, men, women and children, to wither. Messengers (presumably their feet and tongues have been spared!) run and tell the king, whose name is Buz. King Buz interrogates Andrew, who responds by giving him a choice between life and death. The king asks Andrew to heal the populace, which he does with the sign of the Cross. The king declares that he and his people are converted: "We believe in your God." Andrew takes King Buz to his temple and water pours out of the mouths of the idols, flooding the town up to knee-level. The king begs Andrew to help and he causes the water to stop pouring and the idols to be smashed to smithereens. He then stamps his foot and a cistern opens up in the ground to receive the water. He consecrates (this as?) a baptismal font and the people follow their king in receiving the grace of baptism, which changes their dog-like appearance into the beauty of the children of light. The news of their conversion and miraculous transformation spreads throughout the world. Andrew builds a church for them 
and consecrates an altar on which he offers up the Body and Blood of Christ, which which he gives Communion to the people. The ballad ends with a doxology addressed to the Holy Trinity, blessing God for choosing twelve Apostles and sending them to convert the four regions of the world.

In Uppsala I spoke of the connections between this text (which continues for a total of 244 couplets) and two other versions, both unpublished, like this Syriac ballad, one in (Garshuni) Arabic and one in Armenian. The Arabic version seems to have used a lost Syriac prose-narrative, as well as the Syriac ballad. ${ }^{3}$ The Armenian version, in prose, has whole sentences echoing the Arabic; it can be dated around the end of the seventh century. I also compared the story told in this group of texts with that told by Gregory of Tours in his résumé of the Acts of Saint Andrew. Gregory says that Andrew first mission was to rescue Matthias, or Matthew, from the clutches of the cannibals. This account was known throughout the Christian East. The Syriac version of it was published by Wright in 1871.4

The ballad, in contrast with this more widespread version of the legend, does not even mention Matthias. The version which makes Andrew rescue Matthias implies that he is dynamic; the ballad and the related unpublished texts alone stress his advanced age and his debility. It seems to me that the original Acts of Andrew, which were quoted in the third century by the author of the Manichaean Psalms, ${ }^{5}$ must have been longer than any of the extant texts. It would have begun with an episode like that related in the ballad, then Andrew, having discovered the power given to him by Christ, would have set out to rescue Matthias. A magnificent early sixth-century mosaic, in the chapel of Saint Andrew in Ravenna, ${ }^{6}$ represents a very old Andrew with wild hair,

${ }^{3}$ [The Syriac ballad may be a versification of the prose-narrative: Andrew Palmer.]

${ }^{4}$ Reference in M. Geerard, Clavis Apocryphorum Novi Testamenti (Turnhout, 1992) 141-3, no. 236.

${ }^{5}$ C. Allberry (ed.), Manichaean Manuscripts in the Chester Beatty Collection, vol. II, part II (Stuttgart, 1938) 142.

6 F.W. Deichmann, Ravenna: Geschichte und Monumente (Wiesbaden, 1969) 201-6: the chapel was built by Bishop Peter II (AD 494-519). 
contrasting with the much younger Peter. ${ }^{7}$ This representation seems to refer to an ancient version of the legend in which the age of Andrew was stressed, as it is in the ballad.

Geographical excursus: Gregory of Tours tells that Andrew started out to rescue Matthias from a place called Myrmidon. This toponym can be sited precisely. There is a plain formed by a little river called Thermodon, a little to the East of the estuary of the Iris, where that river debouches into the Black Sea. This is the place designated as Myrmidon. In the early Passion of Theodore, Tiron writes that "he was enrolled in the so-called "Marmariton" Legion which was stationed in the town of Amaseia on the Pontos Eixeinos (Black Sea)' and that Saint Christophoros was registered "in the cohort of the Marmaritai." 8 Now Saint Christophoros is a later transformation of the more ancient Chrystomaios, the converted kynokephalos, or "dog-headed man," who, in the Matthias-version of the Acts of Saint Andrew helped that saint and his companions to convert the region. ${ }^{9}$

The last piece in the jigsaw puzzle comes from the preface to the Armenian version of the Passion of Theodore the General. Speaking of Nektanebo, the narrator writes: "He descended in Pontos Polemoniakos, in the Plain of Themiskyrion, next to the river. He settled at the placed named Mamaridon, where the mountains of Pontos start." 10 The Armenian legend mentions the Acts of Andrew in connection with the same toponym. Strabo, a native of Amaseia, says that the Amazons were formerly settled there. ${ }^{11}$ Both the Amazons and the kynokephaloi, who were cannibals, appear in the Alexander-Romance, which began to be edited at the end of the fourth century. ${ }^{12}$ The Syriac ballad seems to

${ }^{7}$ F. W. Deichmann, Frühchristliche Bauten und Mosaïken von Ravenna (Baden-Baden, 1958), plates 233 and 234.

8 H. Delehaye et alii, Acta Sanctorum Novembris, vol. IV (Brussels, 1925), col. 30, with note. The Notitia Dignitatum records a cohors tertia Valeria Marmaritarum.

9 M. Geerard, Clavis Apocryphorum Novi Testamenti, no. 238, p. 144f.: conversio Christomaei in four languages.

10 The text first appeared in the Sop'erk' Haykakank'16 (Venice, 1854) 55-8. It was published again by N. Andrikean in Pazmaveb (1905): 441-8.

11 A. Meineke, Strabonis geographica, I (Leipzig, 1903) 799.

12 J. Trumpf, Vita Alexandri (Stuttgart, 1974) 29,4 and 38,2, pp. 103 and 139 . 
refer to these cannibals with the form of dogs, but it simply calls them "the people of Kalbin" (Syriac kalbe = "dogs"), or Kalboye.

Under this name, "Kalboye," are disguised the Chalybes. We find this name attached to an ethnic group in exactly the same region. The oldest part of the anonymous sixth-century sailing itinerary, or periplous, contains the following words: "From Polemonios up to near the River Thermodon a people called the Chalybes formerly dwelt." 13 Xenophon encountered the Chalybes in this region. The presence of this name, or of a Syriac name evidently representing this Greek name, in our ballad suggests that the source of the ballad is older than that of the Acts of Andrew in the Matthias-version and even older that the Romance of Alexander.

The attribution of the ballad to Ephraim. Assemani found it shocking that the ballad represents Jesus as becoming as it were incarnate for a second time in order to help Saint Andrew. By implication, this “incarnation' suggests a docetic understanding of the first incarnation: He only seemed to be a human being. Nevertheless the poem contains a passage declaring that Jesus was born of a virgin womb, which is Orthodox. We have found some arguments (one from a comparison with other forms of the Acts of Andrew and one from historical geography) which might support a fourth-century date for the ballad and allow us to infer the existence of a third-century Greek original; but it has to be admitted that they are not conclusive arguments. Would Ephraim have been shocked by the idea of Christ becoming the leader of a merchant-caravan? If not, we have to find other reasons for declaring the ballad pseudo-Ephraimic. ${ }^{14}$

13 A. Baschmakoff, La Synthèse des périples pontiques (Paris, 1948) 120, no. 31 .

14 [Having translated a part of the ballad, as well as large quantities of the genuine Ephraim, I should like to add: The Syriac language is imperfectly mastered; the metre is frequently irretrievable, even by emendation; the style is quite unlike that of Ephraim; the ballad lacks sublimity and depth and it fails to play on the similarities between Syriac words, as Ephraim does. It seems to me to be quite late, although the lost prose-version on which it may have been based could be early: Andrew Palmer.] 